\title{
THE EVOLUTION OF SHIVA AND VISHNU IN OC EO CULTURE IN VIETNAM
}

\section{ĐặNG VĂN THắNG ${ }^{1} \&$ LÊ THị SINH HIềN ${ }^{2}$}

${ }^{1}$ Professor, Dr. Faculty of History, University of Social Sciences and Humanities, Vietnam National University-Ho Chi Minh, 10-12 Dinh Tien Hoang, Ben Nghe Ward, District 1, Ho Chi Minh City, Vietnam

${ }^{2}$ Faculty of Oriental Studies, University of Social Sciences and Humanities, Vietnam National University-Ho Chi Minh, 10-12 Dinh Tien Hoang, Ben Nghe Ward, District 1, Ho Chi Minh City, Vietnam

\begin{abstract}
Oc Eo culture in southern Vietnam reflects it is being influenced by Hinduism. Excavations have unearthed many artefacts showing the presence of Hinduism in this region. However, it is interesting that archaeologists found a large number of Shiva sculptures and Shiva related relics such as linga and linga-yoni, which outweigh that of Vishnu during the Oc Eo culture period from the early Oc Eo to post Oc Eo culture. Although many studies on Shiva and Vishnu in Oc Eo culture have been conducted, few of them focus on the evolution of these gods in Oc Eo. Particularly, from the study of Shiva and Vishnu made from bronze, gold and stone, we found that the number of Shiva relics outweigh that of Vishnu and try to address the issue that why Shivaism is more popular than Vaishnavism in Oc Eo culture.

KEYWORDS: Oc Eo, Shiva, Vishnu, Relics, Popular \& Out Weigh
\end{abstract}

Received: Aug 10, 2021; Accepted: Aug 30, 2021; Published: Sep 16, 2021; Paper Id.: IJHRDEC20216

\section{INTRODUCTION}

\section{Oc Eo Culture}

Oc Eo culture existed in present Southern Vietnam from the $2^{\text {nd }}$ century B.C. to the $7^{\text {th }}$ century A.D. and continued to the $12^{\text {th }}$ century A.D. that is known as Post Oc Eo by archaeologists. Based on the relics, especially the pottery found in Tu Tram mound, archaeologists divide Oc Eo culture into three periods as follow:

- $\quad$ Early Oc Eo (the $2^{\text {nd }}$ century B.C. - the $3^{\text {rd }}$ century A.D.)

- $\quad$ Developed Oc Eo (the $3^{\text {rd }}$ century - the $7^{\text {th }}$ century A.D.)

- $\quad$ Post Oc Eo (the $7^{\text {th }}-$ the $12^{\text {th }}$ century A.D.)

Oc Eo was deeply influenced by Indian culture. Indian belief and religion spread over Oc Eo culture and Post Oc Eo right from the beginning of the Funan kingdom. From India, a large number of merchants (Vaishyas) brought silk, mouseline, high quality garments, embroidered clothing, brocade, weapons, oils, carpets, pharmaceuticals, ivory, ivory articles, jewelry and pure gold to Funan. Buddhist monks, Brahmins and Kshatriyas following Hinduism came and settled down in southern Vietnam (Geetesh Sharma 2012, pp.30,55). Oc Eo inhabitants not only imported the quintessential belief and religion of India but also transformed them to suit their

\footnotetext{
${ }^{1}$ Prof.Dr.Faculty of History, University of Social Sciences and Humanities, Vietnam National University-Ho Chi Minh, 1012 Dinh Tien Hoang, Ben Nghe Ward, District 1, Ho Chi Minh City, Vietnam;

${ }^{2}$ Faculty of Oriental Studies, University of Social Sciences and Humanities, Vietnam National University-Ho Chi Minh, 10-12 Dinh Tien Hoang, Ben Nghe Ward, District 1, Ho Chi Minh City, Vietnam;
} 
own culture. Hindu gods are engraved on gold leaves or sculptured on stones. Especially, they sculptured the Buddha on wood and Dharmakaya sutra on a piece of gold. Moreover, they built many Hindu temples in the whole territory of the Funan kingdom. It is recognized that Hindu temples have been developed during the three periods of Oc Eo culture.

\section{Shiva and Vishnu in Oc Eo Culture}

\section{Shiva in Oc Eo Culture}

Shiva (Sanskrit: $\square \square \square$ [6rov], IAST: Śiva, ISO: Śivameans a good omen) is an important god of Hinduism and one of the Trimurti. Shivaism regards Shiva as the Supreme God. His strength was reflected through his multifarious manifestations and his peculiar capacity. Shiva is usually depicted in the form of Shiva linga. Sometimes he is manifested in deep meditation or in the form of Shiva Nataraja (Shiva dancing in a ring of flame) to denote the universe operation (Chigopekar, 1991, p.121). Shiva is the Hindu god of birth and rebirth. Referred to the Vedic god Rudra, he was assisted by his devotees in his great assignment and they also followed him on the mystical path of practice (Craven, 2015, p.36). Shiva is the god of destruction and regeneration. Shiva is white, symbolizing the pure nature of all colors; the three eyes represent the sun, the moon, and the fire of the world, which are able to see through the past, present and future; Shiva's tangled hair represents the god of Wind; The Ganges flowing down Shiva's hair is a sign of purity. Moreover, according to the legend of Shaivite, Shiva was willing to endure the impact of the Ganges river water, not letting water pour down that could destroy the world, by letting river water pour right above the god's head, through the God's tangled hair, it fells smoothly on the ground (Craven, 2005, p.180) and split into the seven sacred rivers of the country of India; in Shiva's bun there is the moon, symbolizing the cycle of time and the time is also indicated of destruction; Shiva has four arms representing the four directions and demonstrating Shiva's domination power. Of the four arms, one hand holding the Vajra trident signifies creativity, conservation and destruction; one hand holding an ax displays absolute strength; one hand signals to dispel fear and the other hand blesses, health, longevity, etc. Shiva's transcendent creative power is the image of Linga. Shiva has a personality that is both hot-tempered, curious and lascivious. He always holds a bow and arrow in his hand, he has conquered his desire in a tiger skin coat, his head is covered with field flowers and his neck with a snake. Shiva is also shown by his wives as Parvati (Bhagavati), Mahishasuramardini (God Durga killed the demon king Mahishasura) (Dharma, 2012, p.101), Uma (the female power of Shiva called Shakti) (Chigopekar, 1991, p.121). Yoni is a symbolic image of Shakti. Moreover, Shiva is often depicted with Nandin, his vehicle and Ganesa, his son (Doan Chinh, 1999, pp.65-67).

According to incomplete statistics, during the Oc Eo and Post Oc Eo period, dating from the second century B.C. to the 12th century A.D., in addition to the images of Shiva, Vishnu and his symbol, incarnations, spouse and vehicle engraved on gold in Go Thap (Dong Thap), Da Noi (An Giang), etc., there are also large numbers of 88 Linga-yoni statues, stone and quartz sculptures. It is interesting that Shiva's symbols outweigh that of Vishnu, which was found only 54 stone sculptures including his head, arms and a bronze statue (Le Thi Lien, 2006, pp.198-204). According to George Coedès, in Funan, Theravada Buddhism existed from the $3^{\text {rd }}$ century A.D. and flourished in the $5^{\text {th }}$ and $6^{\text {th }}$ century under the dynasty of Jayavarman (A.D. 470-513) and Rudravarman (A.D. 514-550). Meanwhile, Shivaism is worshipped in the form of a stone Linga, which was quite popular in the $5^{\text {th }}$ century A.D. (George Coedès, 2008, pp.122-123). However, it is argued that in Funan, Shiva is the Supreme God of Hinduism, Vishnu and the Buddha are the second-rank (Geetesh Sharma, 2012, p.56).

\section{Shiva Engraved on Gold and Bronze}


Shiva depicted on gold is often found in the swastika-shape seima built of bricks deep in the ground in the temple. In India, in the Maurya period (321-184 B.C.), stone carving was very popular and by the Kushan period (A.D. 60-240) there appeared gold coins with legend, one side engraved with the image of King Kanishka in standing posture, on the other side, the image of standing Buddha, attaining a high level of sophistication and perfection (Craven, 2005, pp 47, 103-104). Meanwhile, in Oc Eo, sculptures and symbols of Shiva were depicted on gold. In a number of temples, multifarious symbols of Shiva, his incarnations, his spouse, his vehicle animal, etc., to signify the presence of gods are as follows:

\section{Da Noi Site (An Giang Province)}

\section{+ Shiva temple (Acc.No. 85ĐN. M3)}

The artefacts found in the seima include one gold ring, two pieces of cut coins, one transparent necklace, five different coloured precious gems and 31 gold pieces (Le Xuan Diem, Dao Linh Con and Vo Si Khai, 1995, pp.236-238). Especially, there are seven gold leaves engraved with a standing person having undone his chignon that falls upon his shoulders. Shiva is rarely depicted in human form in Oc Eo culture, and few are found in gold artefacts. Hence, how Shiva is manifested is unknown to many scholars. However, in a site, of 38 gold pieces, there are seven quite similar objects including two Vajras (symbol of Shiva) and two Nandins (Shiva's vehicle), it is possible that the undone chignon standing person engraved on the seven gold leaves are not an ordinary man but Shiva. Another is a stone sculpture of Hari-Hara, a conjoint form of the two gods in one body in Oc Eo culture: the left half representing Vishnu (Hari) and the right half Shiva (Hara). It is the unity of Shiva and Vishnu in Indian art. The above image is represented by a cylindrical hat (Vishnu) under which is the third eye (Shiva) or on the hat, the left half of the statue has a cylindrical shape (Vishnu) and the right half shows the highly curled, ruffled hair (Shiva). According to excavators' descriptions, the gold relics found in the architecture (Acc.No.85ĐN.M3) depict seven undone chignon standing Shiva (Acc.No.85ĐN.M3:11, 85ĐN.M3:12, 85ĐN.M3:13, 85ĐN.M3:14 (Fig1), 85ĐN.M3:16, 85ĐN.M3:17, 85ĐN.M3:18), two Vajra (Acc.No.85ĐN.M3:19, 85ĐN.M3:20) (Fig 2), two Nandin (Acc.No.85ĐN.M3:15, 85ĐN.M3:23).

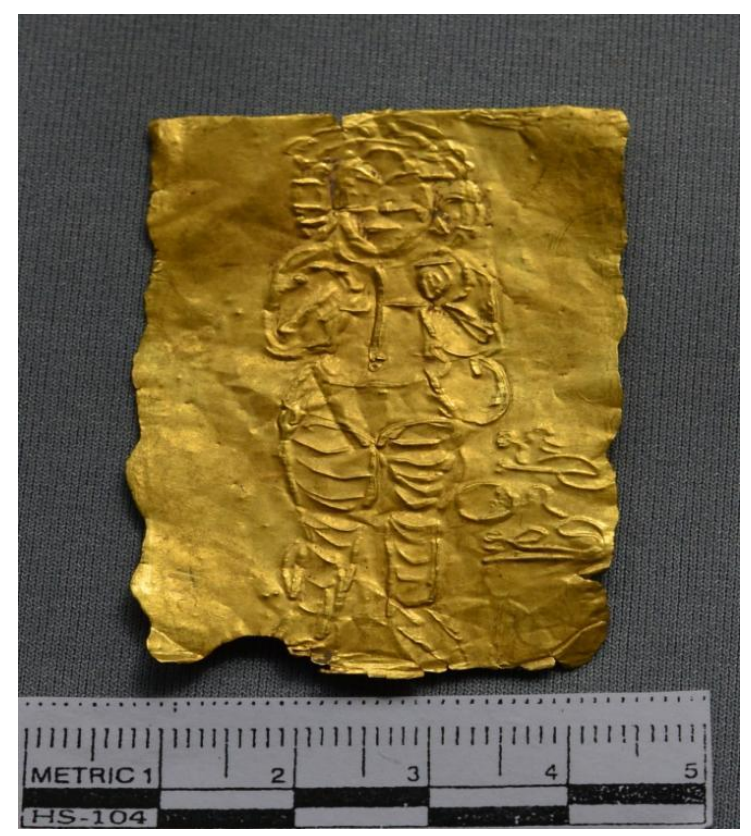

Figure 1: Three-head Shiva on gold leave (85ĐN.M3:14) Source: Dang Van Thang + Shiva and Vishnu Temple (Acc.No.85ĐN.M2)

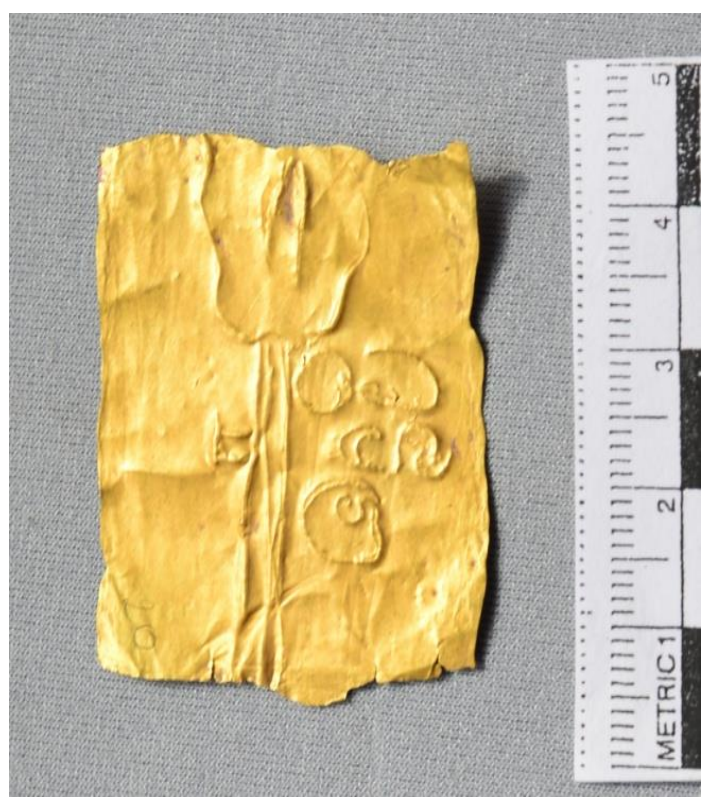

Figure 2: Vajra on gold leave (85ĐN.M3:20) Source: Dang Van Thang 
The artefacts found on the seima include one hundred and three gold pieces, one altar with a gold linga-yoni and one precious gemstone. Most of the laminated gold pieces are small lying in the South and in the most bottom square, covered with the two copper-bowls, inside of which there is an altar having a gold linga-yoni (Le Xuan Diem, Dao Linh Con, Vo Si Khai 1995, 233-234). According to the excavators's descriptions, the gold pieces found in the architecture (Acc.No.85ĐN.M2) depict the features as one Linga-yoni (Acc.No. 85ĐN.M2) (Linga is made of gold and Yoni of tin and copper), seven Nandin (Acc.No.85ĐN.M2:6,85ĐN.M2:7,85ĐN.M2:19,85ĐN.M2:27,85ĐN.M2:27,85ĐN.M2:50, and 85ĐN.M2:58), two Nandin and lotus (Acc.No.85ĐN.M2:32, 85ĐN.M2:33) (Shiva's vehicle and symbol of Lakshmi); one Shesa (Acc.No.85ĐN.M2:25) (Vishnu's vehicle on universe ocean), one Kurma (Acc.No.85ĐN. M2:12) (Vishnu's incarnation), standing Lakshmi holding a lotus (Acc.No.85ĐN.M2:23), one Lakshmi seating in a cross-legged posture on a lotus pedestal (Acc.No.85ĐN. M2:21), and two Lakshmi seating with relaxing legs holding a lotus (Acc.No. 85ĐN. M2:13, 85ĐN. M2:24)

\section{+ Shiva and Vishnu Temple (Acc.No. 85ĐN.M5)}

In this temple, the artefacts found include 17 gold leaves, one black metal piece, one precious stone, one Linga-Yoni (Acc.No.85ĐN. M5:10), one Vishnu holding a sankha (Acc.No.85ĐN. M5:13) (Le Xuan Diem, Dao Linh Con, Vo Si Khai $1995,238)$

\section{Go Thap Site (Dong Thap province)}

\section{+ Vishnu and Shiva Temple (Acc.No.93GT.M1)}

The artefacts found in the seima include fourty nine small gold leaves and a precious orange gem found in the bright gray sand layer at the center (Le Xuan Diem, Dao Linh Con, Vo Si Khai 1995, 247-249). Most of the gold fragments appeared to have been torn from a large piece of gold of which there are thirty three pieces engraved with unclear pictures and sixteen were plain. However, as compared to objects being preserved at Dong Thap Museum, it is possible to figure out the figures on the gold leaves as a chakra (Vishnu's symbol) (Acc.No.93GT.M1.16 (f)), three Varahas (Vishnu's incarnation) (Acc.No.93GT.M1.3(a),93GT.M1.3(e), 93GT.M1.4(e)), three Kurma (Acc.No.93GT.M1.5 (a), 93GT.M1.6 (f), 93GT.M1.7 (b)), one Matcha and one Vajra (Shiva's symbol) (Acc.No.93GT.M1.13 (d)).

\section{+ Vishnu and Shiva Temple (Acc.No.93GT.M4)}

The artefacts found in the seima include 56 gold leaves, three gemstones, seven small green glass and some fragments of copper (Le Xuan Diem, Dao Linh Con, Vo Si Khai 1995, 249). The gold leaves depict two Vishnu holding a sankha in the left hand and chakra in the right hand (Acc.No.93GT.M4.1 (d), 93GT.M4.2 (d)), three chakars (Acc.No.93GT.M4.3 (d), 93GT.M4.10 (a), 93GT.M4.19 (c)), one Garuda (Vishnu's vehicle), two Lingas (Shiva’s symbol) (Acc.No. 93GT.M4.8 (b), 93GT.M4.13 (b)).

\section{+ Vishnu and Shiva Temple (Acc.No. 93GT.M5)}

The artefacts found in the seima include 72 gold objects, two gold rings and one gemstone (Le Xuan Diem, Dao Linh Con, Vo Si Khai, 1995, pp.249-250). The gold leaves depict the figures of Chakra, Chakra and Sankha, Sankha, Sankha and Lotus, Lotus, Garuda, Matcha, Nandin. They all are kept at Dong Thap Museum.

\section{+ Shiva and Vishnu Temple (Acc.No. 93GT.M3)}


The artefacts found in the seima include 34 gold leaves and one orange-red bead found in the soft white sand layer at the architecture center (Le Xuan Diem, Dao Linh Con, Vo Si Khai, 1995, p.245). The gold leaves depict Vajra, Chakra and lotus and Shesa.

\section{Shiva Depicted on Bronze}

A bronze Shiva was found in the area of Tay An pagoda, Mount Sam (Phnom Svam) (Chau Doc - An Giang). The sculpture is in a standing posture, with one hand raised forward, long fingers curled into a lion's ear called Kataka hasta. In the right hand, the thumb is stuck to the tip of the index finger, in the left hand, the thumb is broken. The hair is depicted in parallel threads, forming a high tuft and then falling down. On the bun, there is a broken jewelry pattern. The face is oval with crescent-shaped eyebrows, open eyes, straight nose, thick lips. Shiva is wearing a plain short-length sampot, which is slightly folded up. The belt is straight. The loom head is pulled under the waist in three irregular folds. Its replica is preserved at Sai Gon Museum (Acc.No.3426) (Louis Malleret, 1960, pp.208-209). The sculpture is dated back to the 12 $2^{\text {th }}$ century A.D.

\section{-Shiva Depicted on Stone}

Stone sculptures of Shiva in human form belong to Post Oc Eo period (the $7^{\text {th }}-12^{\text {th }}$ century A.D.) and few in Oc Eo culture. However, the most popular manifestation of Shiva is in Linga or Linga-yoni form.

\section{+ Shiva Óc Eo}

The sculpture is made of sandstone, $0.37 \mathrm{~m}$ high wearing only a hat, with the broken chest and a part of the right arm. This sculpture is similar to the Shiva in Kompong Cham Kau being preserved in Pnompenh Museum. It has the hair of Jatamuruta style but can be seen from the back. The braids are upward plaited into tufts with weft strings. In the front, a head belt has two rounded tips and a convex moon face in the center, quite prominent on the two sides; the frilly hair reveals a brim that contains a lanceolate graphic. The face was greatly damaged, leaving only the left side in an oval shape. Long earlobes are wearing inverted flowers. The right hand is slightly arched back, the arm is brought forward. This Shiva sculpture was found at the Hoi Long pagoda, Kien Hao, Gach Gia, Oc Eo field being preserved at MBB, $n^{0} 4224$ (Louis Malleret, 1959, pp.375-376). The head decorations reflect Ardhanarisvara, half male and half female Shiva (Le Thi Lien, 2006, p.80).

\section{+ Shiva Ba The}

The sculpture is made of sandstone, $0.44 \mathrm{~m}$ high. It has a hair tuft in Jatamukuta style similar to the Harihara sculpture at the Guimet Museum (Louis Malleret, 1959, pp.376-377). Characteristically, the hat is made up of a tall bun, with many curls falling around in three layers. The forehead has the blond as a flower (Le Thi Lien, 2006, p.80).

\section{+ Seated Shiva}

The two sculptures were found when excavating at Go Don in 1987 and they are kept in Long An Museum. The stone sculpture (Acc.No.87LA93GĐ 35 (stone)) is $0.285 \mathrm{~m}$ high, made of white sandstone. This is a sculpture carved in a seated posture, the legs forward, the hands on thighs. The upper part of the helmet is cylindrical, with a vertical engraved line; The lower part is a wide, thick crown that holds the hair at the forehead and a small wire goes around the back to hold the hat. On the rim is engraved with the petals of a large flower. The hair is braided in small and regular curls, curled upward. In addition to the rim, the forehead has a translucent line that runs around the hair. The sculpture's face is round, quite 
fierce. The forehead is short, flat with two large, well-raised eyebrows that are arched and rounded at the tip of the bridge of the nose. The fierce eyes are convex and round, with no eyelids. The nose is low and wide. The mouth is wide, whose lips are thick and protruding in front. Under the mouth is a hat-shaped beard represented by a floating plate extending from the ear to the chin, the big ears lengthening down to the shoulders and short neck. Under the neck, there is a decorative ring in the front of the chest and on the back. Wide bibs are in the middle, narrowing to the shoulders. In the middle of the bib is a high floating object, the upper part is oval, the lower part is triangular. The body is wrapped in a sampot whose front is sagging down; the front of the sampot has the knots on the back without folds, while the back has a shape of floating lines running around and a large five-petal flower in the middle of the spine, near the buttocks. The sculpture's legs are broken. However, through the rest of the right thigh, we can see the sculpture carved in a seated posture with legs stretching out in a V-letter shape.

The second Shiva sculpture (Acc.No.87LA93GĐ36 (stone)) is made of white gray sandstone, which is quite intact. He wears a cylindrical hat, whose top is quite square and the surface is decorated with top-down patterns. The crown belt, which is decorated with two linked pattern ribbons is widen covering the head to the ears. The sculpture has a large face, flat forehead, curved eyebrows separated and symmetrical, small and convex eyes, flat and widen nose, thick and open lips. The big ears wear jewelry lengthening to the chin. The sculpture head and its crown decorations are similar to Shiva sculpture (Acc.No. 87LA93GĐ35 (stone)). These two sculptures are dated back to the 7th century A.D. (Le Thi Lien, 2006, p.81). They are similar to the Indian Shiva sculpture being preserved at Open Air Jardin Museum, Khajuraho (Acc.No.0544).

\section{+Shiva Assis à L'aisance Royale}

This sculpture associated with a Linga is $1.25 \mathrm{~m}$ high, formerly placed on the top of Mount Sam. At present, it becomes the main worshiping image of Ba Chua Xu Temple, Mount Sam, Chau Doc, An Giang. The interesting features of the sculpture are its posture and hair. The seating posture is comfortable like a king, the left foot stretched to the ground, the right leg bent straight forward, the right hand with its fingers outstretched on the knee, the left hand spread flat on the ground, which is described in ancient Chinese bibliography as the seating style of Funan King and is often found on the lower reliefs of Angkor Wat. The hair is braided on top of the head in distinct braids, under the hat decorated with overlapping rings. The bottom is a stone three-piece ring, probably hanging patterned belt that radiates forward and down to the earlobes (Louis Malleret 1959, 373-375). The sculpture is dated back to the late 12th century A.D.

\section{+ Harihara Óc Eo}

Harihara is a union of two gods, Hari corresponds to Vishnu and Hara to Shiva. The head of the Harihara Óc Eo sculpture is being kept at An Giang Museum (Acc.No.BTAG Đa.05), with a tube-shaped, slightly oblong helmet (the symbol of Vishnu). The face shows a lively, realistic, chubby and round chin, deep eyes, protruding, clear eyelids, massed eyebrows, and a third eye on the forehead (symbol of Shiva). The nose is short and thick, the lips are thick without borders, a little smiling. The earlobe is long and round, whose lower part is broken. The sculpture dated back to the 5th century A.D. (Le Thi Lien, 2006, p.81).

\section{+ Harihara Ba The}

The head of Harihara Ba The sculpture was found at the entrance of Linh Son pagoda, made of sandstone, $0.31 \mathrm{~m}$ high. It is preserved at the Musée Blanchard de la Brosse (now Ho Chi Minh City History Museum), (Acc.No.MBB, $n^{0} 2939$ ) (Louis 
Malleret, 1959, pp.409-410). The sculpture's head wears a tubular hat divided evenly into two halves. The left half has a tubular shape, slightly oblong, with a flat top (symbol of Vishnu); in the right half the hair is arranged in a high knot, the front is attached with a bow, the curls spread out to the sides like a petal, the third eye in the middle of the forehead is shown half (Shiva's symbol). The face is slightly long with long eyebrows. Eyes are shown double eyelids and irises (lively eyes), straight and long nose, wide mouth with deeply contoured lips. This sculpture is similar to the Lakshmi Kohkrieng dating to the 7th century A.D., belonging to the early period of the Prasat Andet style (Le Thi Lien, 2006, pp.81-82).

\section{The Development of Linga}

Shiva is expressed in a form of Linga. In Oc Eo culture, Linga-Yoni symbol existed since the early period of Oc Eo culture and became very popular in the Post Oc Eo period. Linga is also very popular in India and found in many villages, or in temples (Louis Malleret, 1959, p.377). According to statistics of Le Thi Lien, in southern Vietnam, 86 terracotta, stone and quartz Linga-yoni were found including nine naturalistic Lingas, fourteen linga-Yoni, seventeen three-part Linga and four two-part Linga (Le Thi Lien, 2006, pp.201-204).

In terms of typology, we can recognize the evolution of the Linga and Linga-Yoni in Oc Eo culture as follows:

Naturalistic Linga (the $2^{\text {nd }}$ century B.C.) $\rightarrow$ Linga-Yoni (the $4^{\text {th }}$ century A.D.) $\rightarrow$ three-part Linga (the $5^{\text {th }}$ century A.D.) $\rightarrow$ two-part Linga (the $7^{\text {th }}$ century A.D.)

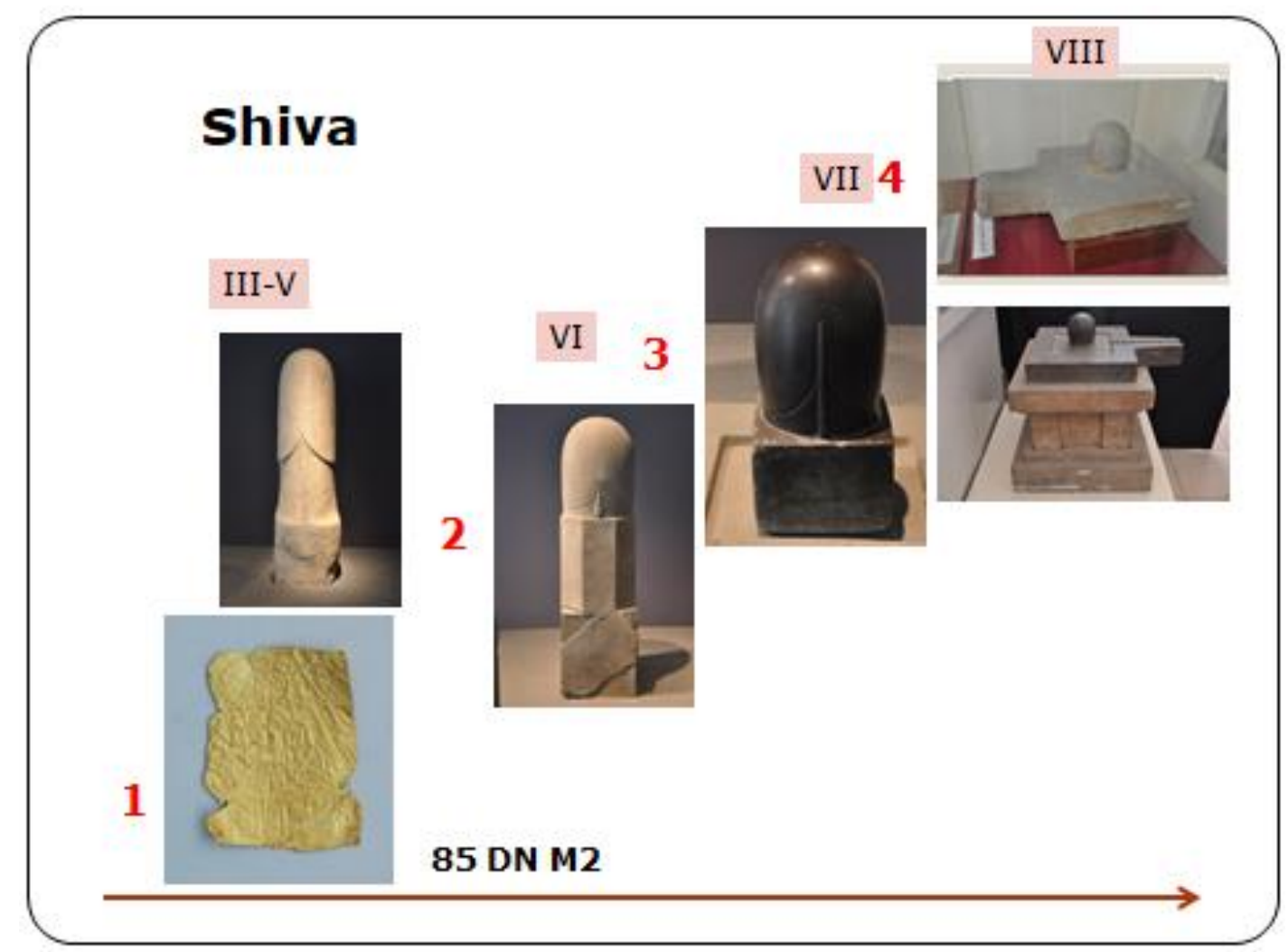

Figure 3: Development of Linga and Linga-Yoni in Oc Eo culture.

\section{Vishnu in Oc Eo Culture}

Vishnu is considered an all penetrated and divinified god of the Indian panthenon. He is at the center of vast mythology through his manifold incarnations. He is one of the Indian Trimurti: Brahma (Creator), Vishnu (Preserver) and Shiva 
(Destroyer). Vishnu is usually depicted lying on the serpent Shesha with many heads (five heads, seven heads) or standing with four hands holding four objects: the plate (the symbol of wisdom and the sun, but the sun represents the domination of the universe), the sankha shell representing the "Om" sound that basically vibrates so that there can be creation. Blowing the sankha shell signifies the presence of Vishnu, lotus representing the purity of the universe and the fertile land and a mace representing knowledge and bhodi, control capality, authority and order maintainance. Vishnu has ten incarnations: Matcha, Kurma, Varaha, Narasimha, Vamana, Parashurama, Rama, Krishna, Buddha, Kalki (John Bowker, 2003, pp.4244).

\section{Vishnu Engraved on Gold in Oc Eo Culture}

Vishnu is crafted in a wide range of images on gold leaves found in religious Da Noi site An Giang and Go Thap site (Dong Thap). Vishnu is manifested in human form, in various incarnations, symbols and even his vehicle.

There are four Vishnu images engraved on the four gold leaves in Da Noi temples (Acc.No.85ĐN.M2.09, 85ĐN.M2.10,85ĐN.M4.39, and 85ĐN.M5.13). Vishnu is standing, wearing a cylindrical hat and a dhoti. The two Vishnu sculptures (Acc.No.85ĐN.M4.39 and 85ĐN.M5.13) have four arms, in which the first hand is holding a sankha, the second holding the Kaumodaki, and the left two hands holding something unclear. It is possible that the left two hands are holding a Padma and Sudarsanan or Vajranabha given by Agni when Vishnu defeated Indra according to an Indian legend (Huynh Thi Duoc, 2005, p.58). The two sculptures (Acc.No.85ĐN.M2.09 and 85ĐN.M2.10) have only two arms, in which the sculpture (Acc.No.85ĐN.M2.09) holds a sickle in its right hand and the sculpture (Acc.No.85ĐN.M2.10) holding a sickle in its left hand. The artefact (Acc.No.85ĐN. M5:13) is crafted with other symbols such as a Padma, a circle, and a jug (Le Thi Lien, 2006, p.131).

Vishnu in human form in Da Noi site is different from Vishnu found in Go Thap site. The two Vishnu sculptures in Go Thap (Acc.No.93GT.M4.1 (d) and 93GT.M4.2 (d)) hold a sankha in its left hand and a chakra in his right hand, standing in abhyanga posture. He wears a short, thin sampot with many folds, tighten to the body (fig.4). These golds leaves appear together with other fragments having 'Sri' letter, a southern Indian feature, dating back to the $4^{\text {th }}$ and the $5^{\text {th }}$ century A.D. (Le Thi Lien, 2006, p.131).

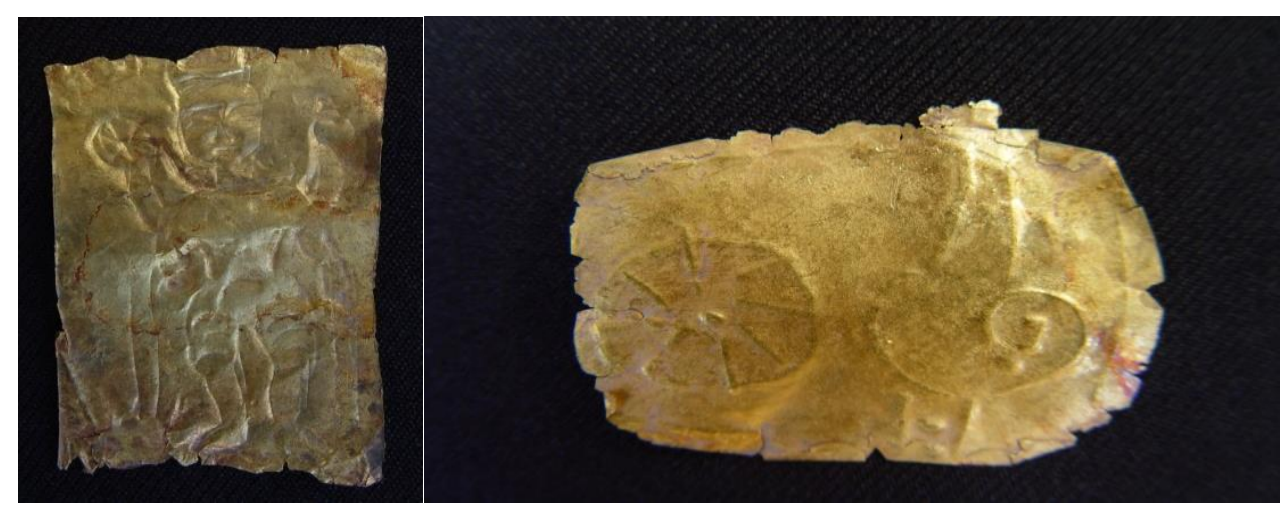

Figure 4: Vishnu and his Symbols on Gold.

Source: Dang Van Thang (Acc.No. 93GT.M4.1 and 93GT.M5.10)

Two Matsya images with horizontal viewing posture (Acc.No.85ĐN. M4:10 and 85ĐN. M4:112) were found in 
Da Noi Site (Acc.No.85ĐN. M4), two images of matsya in swimming and catching bait (Acc.No.85ĐN.M3:28 and 85ĐN.M3:31) found in Da Noi site (Acc.No.85ĐN. M3) and three images (Acc.No.93GT.M1.11, 93GT.M5.28 and 93GT.M5.40) were found in Go Thap site (Acc.No. 93GT.M1 and 93GT.M5).

\section{+ Vishnupada}

The myth of Vishnupada, the footprint of Vishnu, is narrated in the Vayu purana that Vishnu as the dwarf tricked demon king Bali into giving him the space so that he could cover it in three strikes. He then stepped over the heaven, sky, earth and the whole universe (Hasan 1993, 336). Vishnu is also known as Trivikrama. An inscription dated back to the $5^{\text {th }}$ century A.D. in Go Thap mentioned prince Gunarvarman commanding to build the Vishnupada (Le Thi Lien 2006, 134). The ninth verse of the inscription wrote that this Vishnupada is offered to gods by Brahmins who have the best knowledge of Vedas, Upaveda and Vedanga (Le Huong 1974, 45). In Da Noi Site (Acc.No.85ĐN. M4), two artefacts (Acc.No.85ĐN.M4:103 and 85ĐN.M4:129) were crafted clearly and naturally. Two feet were crafted out separately, the right and the left feet are quite similar in size with meticulous and short toes and slightly curved brim. It is possible to be the Vishnupada in Hinduism (Le Xuan Diem, Dao Linh Con, Vo Si Khai, 1995, p.348).

\section{+ Shesha}

Shesa, Vishnu's vehicle on universe ocean, appears regularly in sites of Oc Eo. Five-head Shesa was found in Da Noi site. The Shesa image (Acc.No.85ĐN.M2:25) found in the site (Acc.No.85ĐN.M2) and the image (Acc.No.85ĐN.M3:14) found in the site (Acc.No.85ĐN.M3) were simply crafted. The Shesa image (Acc.No.85ĐN.M4:62, 85ĐN. M4:75, 85ĐN.M4:97, 85ĐN.M4:109, 85ĐN.M4:159) found in the site 85ĐN.M4 were crafted similarly with curved and detailed body. The Shesa image usually appears with other symbols like sankha and chakra on the same gold leave (Lê Thị Liên, 2006, p.135). Especially, in Go Thap, one image of Shesa (Acc.No.93GT.M3.14 (c)) was found.

\section{Vishnu Engraved on Stone}

\section{Sculptures with U-Shape Support or an Arch behind the Hat}

The 1994 excavation at the Binh Thanh temple (Tay Ninh province) found the two lower ground plans than the present one with average-size bricks, step well and Vishnu sculpture. Pham Nhu Ho claimed that Binh Thanh site has two stages of development: the early stage had lower ground plan and stepped well (the $7^{\text {th }}$ the $8^{\text {th }}$ century) and the later stage with the present temple (the $9^{\text {th }}$ - the $10^{\text {th }}$ century) (Pham Nhu Ho 1996, 68-72). The Binh Thanh Vishnu scultprue has the only Ushape support without body, wearing a cylindrical hat. The left hand holds a sankha and the right hand a discus. The sculpture is similar to later Prasat Andet style and Kongpong Preah (Le Thi Lien, 2006, p.70). However, its smooth features reflect the influence of Phnom Da style, dating back to the $7^{\text {th }}$ century A.D.

The 1998 excavation at the southern ground wall of Go Thap Mound (Dong Thap) found the two Vishnu sculptures (figure.5). The first sculpture is $54.5 \mathrm{~cm}$ high, standing upright with four arms. The two upper hands are broken, the upper left hand holds a sankha and the lower left hand a plain and round stick. The support behind the head is curved, the cylindrical hat is plain and straight lengthening down the ears. He is wearing a knee-length sampot, wrapped into a small circular button and then falling down in fishtail-shaped folds. This style of sculpture was dated back to the late $6^{\text {th }}$ century and the early $7^{\text {th }}$ century A.D. by Pierre Dupont (Le Thi Lien 2006, 72-73). The second Vishnu sculpture found at Thap Muoi Mound was crafted in gray stone, $0.965 \mathrm{~m}$ high. Its support from head to arms was broken. It has four arms with the upper right hand holding a chakra, the lower right hand fisting on the stick with slightly curved quadrilateral section. 
The upper left hand is broken, the lower left hand holds a round stick. The hat is plain and becomes smaller in the top. He wears a long dhoti. The sculpture pedestal is rectangular with a big latch. It is dated back to the $7^{\text {th }}-8^{\text {th }}$ century (Le Thi Lien, 2006, pp.69-70).

Another Vishnu sculpture found at Chot Mat (Tay Ninh province) is $55 \mathrm{~cm}$ high and preserved at Ho Chi Minh City Arts Museum with Acc.No. BTMT.187 (Lam Quang Thuy Nhien 2005, 44). The Chot Mat Vishnu sculpture wears a short sampot with a belt and a piece of clothing towards the right leg and it is dated back to the $8^{\text {th }}$ century by Pierre Dupont (Louis Mallerete 1963, 81-82). Another Vishnu with U-shape support is quite intact found in the Tuy Hoa temple (Binh Thuan province) and being kept at Vietnam National History Museum (Ngo The Phong, 2012, pp.40-48). This sculpture belongs to Phnom Da style, dating back to the $6^{\text {th }}$ century (Khun Samen, 2008, p.51).

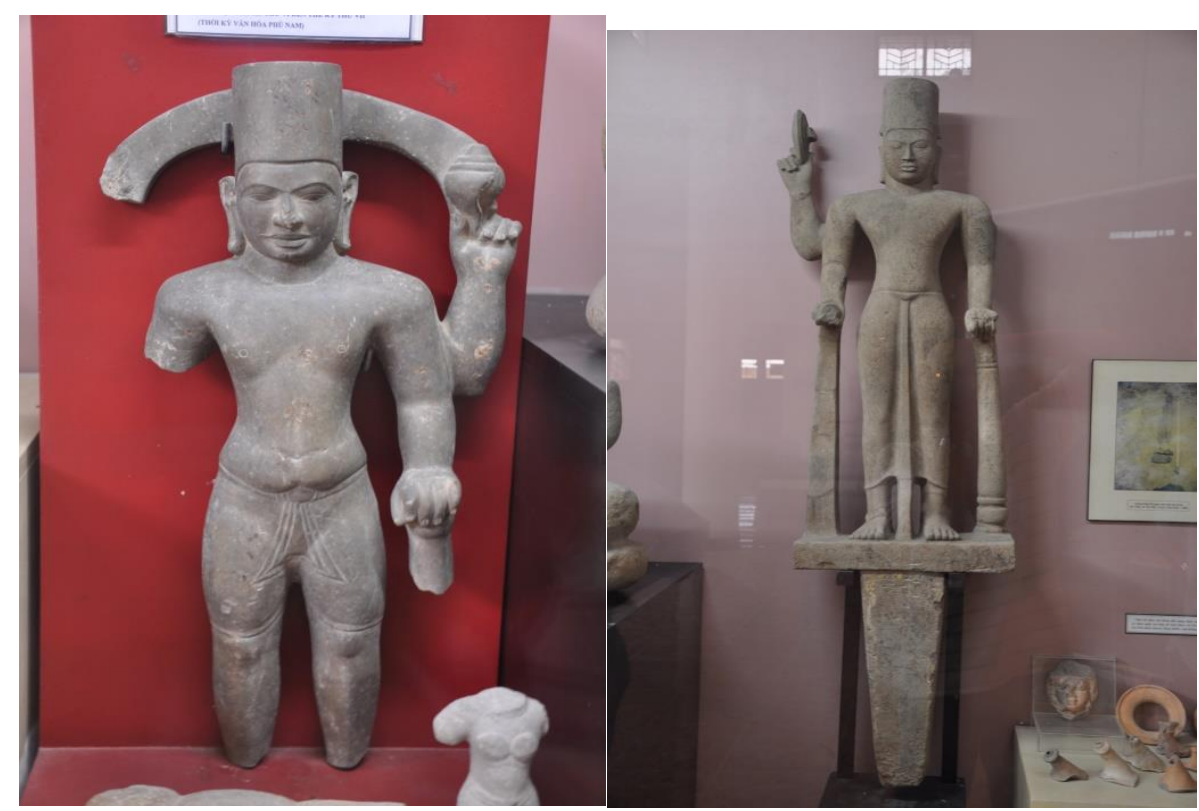

Figure 5: Vishnu in Gò Tháp Mười (Đồng Tháp).

Source: Dang Van Thang

Other Vishnu sculptures such as Vishnu Go Thanh (Tien Giang), Vishnu Phuoc Luu (Tay Ninh) are relatively fatter and shorter (Le Thi Lien, 2006, pp.70-71). These are dated back to the $7^{\text {th }}$ cenutry A.D.

\section{Sculptures without Support behind the Hat}

The sculpture of Vishnu Oc Eo (An Giang) is standing with four arms. The two upper arms are broken, the two lower arms rest on the hip. The right hand holds a blossom lotus, the left hand holding a sankha. He wears a tube-shape hat and an ankle-length dhoti with a piece of clothing falling in the front. The belt is plain with a U-shape clothing in the front (Le Thi Lien 2006, 67). It is kept at Ho Chi Minh City Histoy Museum with Acc.No.BTLS.5528. The Vishnu Vong The (An Giang) has four arms but without head. The difference between Vishnu Oc Eo and Vishnu Vong The is that the lower right hand of the later holds a ball (Le Thi Lien 2006, 68). It is kept at Ho Chi Minh City History Museum with Acc.No.BTLS.5529. These sculptures are dated back to the $8^{\text {th }}$ century (Fig.6). The Vishnu Kien Hoa (Ben tre) has four arms. It wears a pointed brim hat similar to Angkor Wat style, dated back to the $12^{\text {th }}$ century (Khun Samen, 2008, p.82). It is kept at Ho Chi Minh City History Museum with Acc.No.BTLS.5593. 


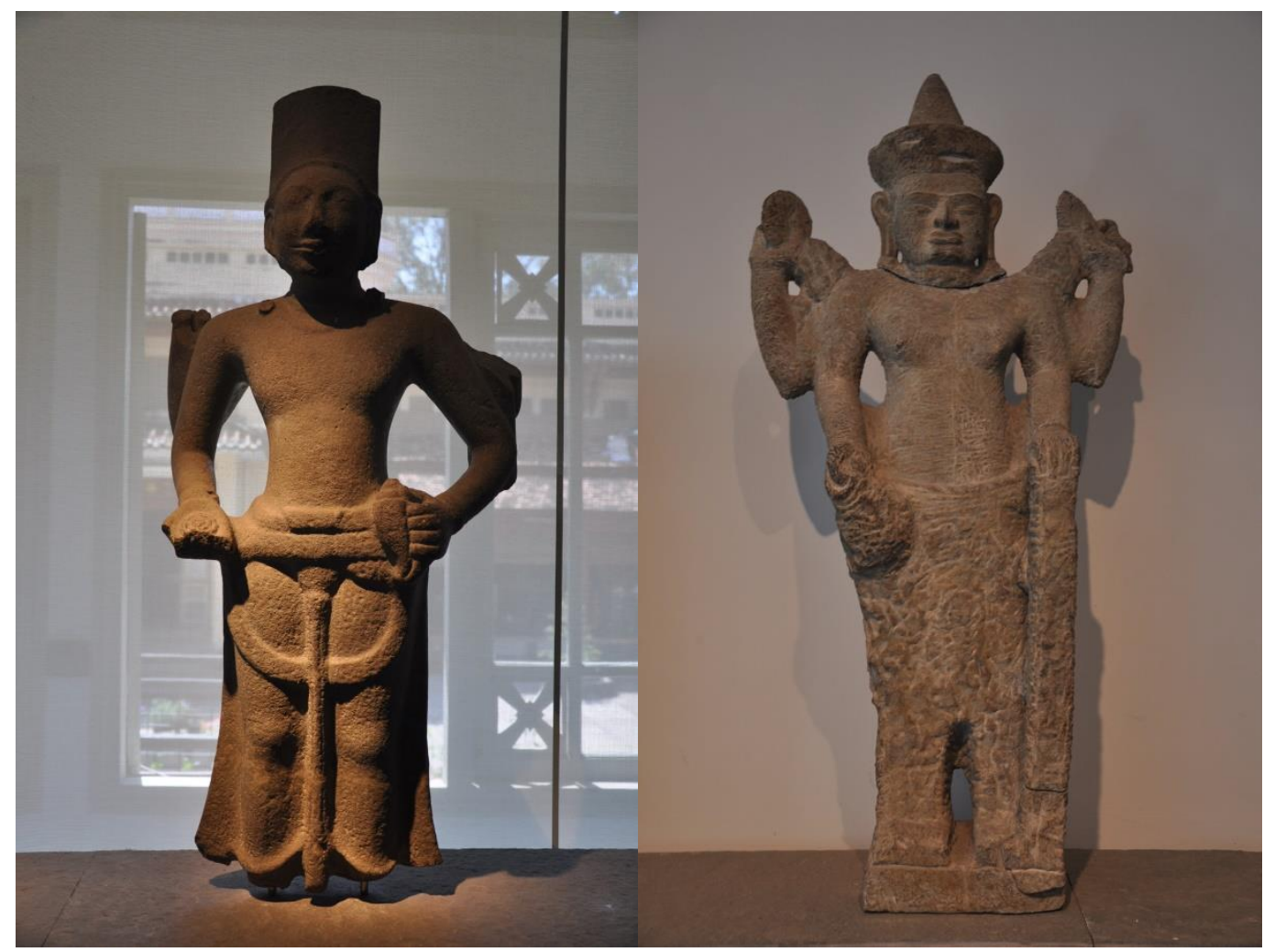

Figure 6: Vishnu

Source: Dang Van Thang

\section{DISCUSSIONS}

Based on typology method, stone Vishnu sculptures in Oc Eo culture can be recognized their development process as follows:

- Vishnu sculptures dated back to the $\boldsymbol{6}^{\text {th }}$ century have the U-shape support or an arch behind the hat, which is cylindrical. They wear a short sampot usually with a fishtail shape in the front.

- Vishnu sculptures dated back to the $7^{\text {th }}$ century have the horizontal support behind the hat, which is cylindrical. They wear a short sampot with the two fishtails in the front.

- Vishnu sculptures dated back to the $8^{\text {th }}-$ the $12^{\text {th }}$ century do not have the support behind the hat, which is a tube with a brim similar to Angkor Wat style. They wear a long dhoti, with a waist belt and a U-shape clothing in the front.

Those Vishnu Oc Eo sculptures were usually found at completely brick-built temples. It is possible that these sculptures were placed in these temples. While the temples simply built with bricks have the Swastika seima in the center under which there are Vishnu images, his symbols, his incarnations, his vehicles crafted on thin gold leaves, which are kept in the ground for safety and to reflect the presence of gods in Hindu temples which are mistaken as cremation graves by some Vietnamese archaeologists. Hence, these Vishnu images on gold and simple brick-built temples may be dated earlier than stone Vishnu sculptures and completely brick-built temples, which maybe are dated back to the $4^{\text {th }}$ - the 5 th century A.D. The development process of Vishnu in Oc Eo culture is manifested in figure 7 as follows. 


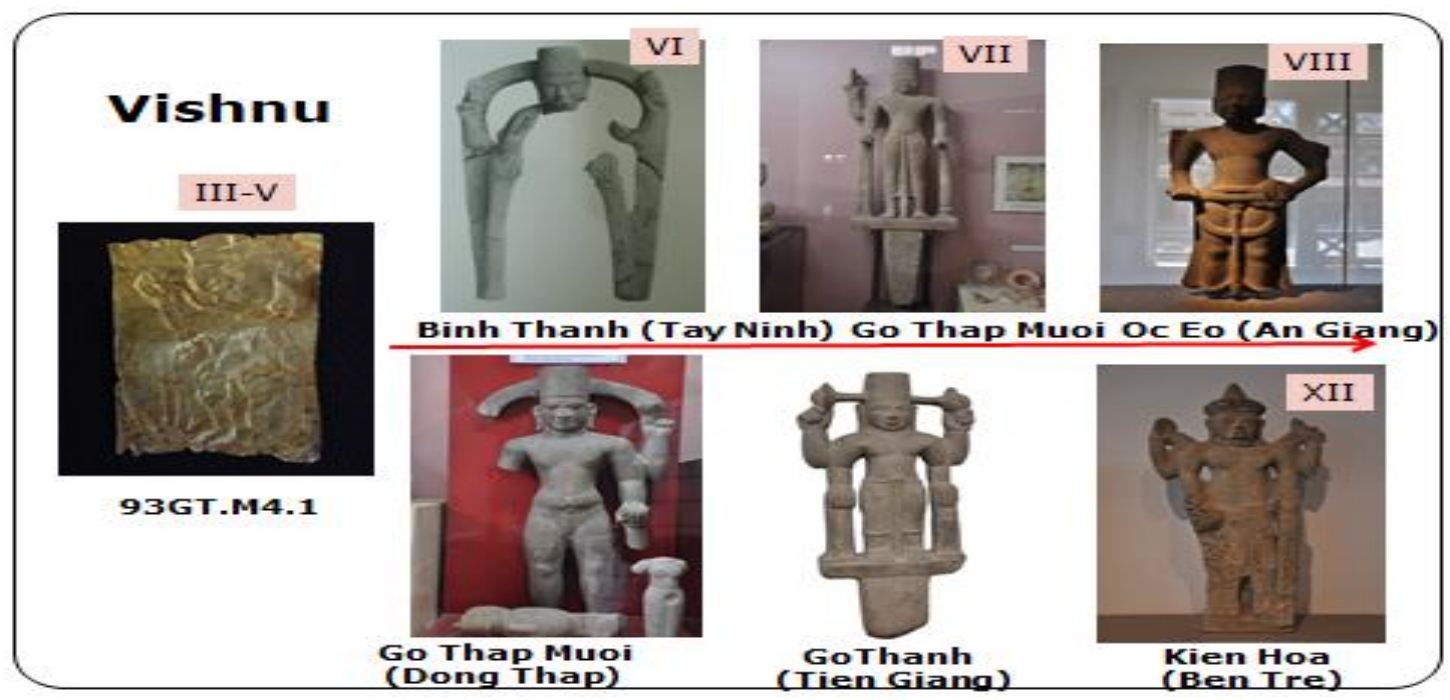

Figure 7: Development of Vishnu in Oc Eo culture (Source: Dang Van Thang).

\section{CONCLUSIONS}

- Shiva is the most important god in Oc Eo culture, appearing in Oc Eo from the beginning of this culture to the Post Oc Eo period. Through the study, we can see that the number of Shiva artefacts outweighs that of other gods. For the stone artefacts, there are 88 Shiva objects while there are only 53 Vishnu ones.

- In the early Oc Eo period, the naturalistic Linga was in a simple form. The standing Shiva image with blond hair was crafted on gold in addition to Linga image, Linga-Yoni, Vajra image, Linga sculpture, and Nandin, Shiva vehicle. From the developed Oc Eo period to Post Oc Eo, Shiva was manifested in the form of Linga or LingaYoni.

- In terms of typology, Linga in Oc Eo culture may be developed as follows: Naturlaistic Linga (the $2^{\text {nd }}$ century B.C.) $\rightarrow$ Linga-Yoni (the $4^{\text {th }}$ century A.D.) $\rightarrow$ Three-part Linga (the $5^{\text {th }}$ century A.D.) $\rightarrow$ Two-part Linga (the $7^{\text {th }}$ century A.D.)

- Vishnu and his incarnations in Oc Eo culture were previously crafted on gold and placed in the swastika seima under the ground. Then they were crafted on stone placed in the brick-built temples from the $4^{\text {th }}$ century to the $12^{\text {th }}$ century A.D.

\section{REFERENCES}

1. Craven, R.C., 2005: Indian Arts, translated by Nguyen Tuan, Huynh Ngoc Trang. The Arts Publisher

2. Con, Dao Linh, 2010: Minh Su Mound (Go Thap Site, Thap Muoi District, Dong Thap Province). Excavation Report. Go Thap Management Committee reference.

3. Chinh, Doan, 1999: Indian Philosophical History, The Youth Publisher.

4. Thang, Dang Van, 2012: Oc Eo Bricks - Forms and Recognitions. Hanoi: Social Sciences Publisher.

5. Coedès, G., 1964:Some Problems in the Ancient History of the Hinduized States of South-East Asia, Journal of Southeast Asian History 2, 1-14. Google Scholar 
6. Coedès, G., 2008: Ancient History of the Indianized States in the Far East, translated by Nguyen Thua Hy. The World Publisher.

7. Sharma, G., 2012: Indian cultural imprints in Vietnam, translated by Ven.Tri Minh, Ho Chi Minh City Culture and Arts.

8. Bowker, J., (Ed.), 2003: The World Religions, translated by Nguyen Duc Tu and Quynh Hai Ha, Culture and Information Publisher.

9. Samen, Kh., 2008: The New Guide to the National Museum Phnom Penh. Phnom Penh: Ariyathoar.

10. Nhien, Lam Quang Thuy, 2005: Stone Sculptures in the southern Delta, Ph.D.Thesis submitted to History Faculty. Institute of Southern Social Science.

11. Huong, Le, 1974: Funan History. Nguyen Nhieu.

12. Lien, Le Thi, 2006: Buddhist and Hindu arts in the Mekong Delta before the $10^{\text {th }}$ century, The World.

13. Diem, Le Xuan, Con, Dao Linh, and Khai, Vo Si, 1995: Oc Eo Culture New Discoveries. Social Science.

14. Malleret, L.,1959:L'Archéologie du delta du Mékong, tome premier : L'Exploration Archéologique et les fouilles d'Oc-Eo. École Francaise D'Extrême Orient, Paris.

15. Malleret, L., 1960:L'Archéologie du delta du Mékong, tome second : La Civilisation Matérielle d'Oc-Èo. École Francaise D'Extrême Orient, Paris.

16. Malleret, L.,1963:L'Archéologie du delta du Mekong, Tome Quatrième: Le Cisbassac. École Francaise d'Extrême Orient, Paris.

17. Phong, Ngo The, 2012: Notes on the Two Sculptures in Oc Eo-Funan Exhibition, Scientific Information 2, 40-48.

18. Ho, Pham Nhu, 1996: Binh Thanh Temple (Tây Ninh) in the Context of the Southern Ancient Temples, Archaeology 4,68-72.

19. Srinivasan, R., 2012. India: A Spiritual Kingdom, The Labour Publisher.

20. Hirano, Y., 2009: The study of the cultural exchange of Oc Eo cultural sites in Mekong Delta: from pottery and roof tiles found from Go Tu Tram site (2005-2006). Read at IPPA International Congress $5^{\text {th }}$. Dec. 2009, Hanoi Publisher.

21. Kumar, S. V., and Singh, M.R., 2019: Salt Weathering of 7th Century CE Granite Monument of Shore Temple, Mahabalipuram-Scientific Investigation and Conservation Strategy, Heritage 2019, 2(1), 230-253. Google Scholar

22. Huntington, S.L., 1990: Early Buddhist Art and the Theory of Aniconism, Art Journal 49, 401-408. Google Scholar

23. Ju-Hyung Rhi, 1994: From Bodhisattva to Buddha: The Beginning of Iconic Representation in Buddhist Art, Artibus Asiae 54, $207-225$. Google Scholar

24. Pal, P., 1996:Sculptures from South India in The Art Institute of Chicago, Art Institute of Chicago Museum Studies 22, $20-35+94$. Google Scholar

25. Chitgopekar, N.,1992: Some Aspects of Shivaism In Madhya Pradesh c.AD. 550 - 1300, Proceedings of the Indian History Congress 52, 121-128. Google Scholar

26. Singh, R.P.B.,1993: Cosmos, Theos, Anthropos: An Inner Vision of Sacred Ecology in Hinduism, National Geographical Journal India 39, 113-130. Google Scholar

27. Badlani, H.G., 2008: Hinduism: Path of the Ancient Wisdom, iUniverse.

28. Hasan, P., 1993: The Footprint of the Prophet, Muqarnas 10, 335-344 in Honor of Oleg Grabar (1993), Brill. Google Scholar 
29. Thuy, Vo Thi Thu. "Some Solutions to Adapt to The Natural Conditions in the Traditional Houses of People in the Mekong Delta, Vietnam." International Journal of Environment, Ecology, Family and Urban Studies (IJEEFUS) 10.1, Feb 2020, 35 48

30. Thi, Hue Hoang, and HaHoang Thi Hong. "Acculturation in Vietnamese Contemporary Literature." International Journal of Communication and Media Studies (IJCMS) 6.3 (2016).

31. Thitinh, Nguyen, Kieuthi Thu Chung, and Huynh Tan Hoi. "Vietnamese Youth and the Standards of Family and Social Success." International Journal of Mechanical and Production Engineering Research and Development (IJMPERD)10.3, Jun 2020, 2301-2306

\section{ACKNOWLEDGEMENTS}

The authors would like to thank the University of Social Sciences and Humanities, National University-HCMC for supporting this paper.

\section{RECENT PUBLICATIONS}

- Thắng, Đặng Văn, 2017: Hindu Temples in Go Thap, Dong Thap Province, Vietnam, American Sciences Research Journal for Engineering, Technology, and Sciences (ASRJETS), Vol 30, No1 (2017), pp.385-395, ISSN (Print) 2313-4410, ISSN (Online)

2313-4402. http://asrjetsjournal.org/index.php/American_Scientific_Journal/article/view/2874

- Thắng, Đặng Văn and Sen, Võ Văn, 2017: Recognition of Oc Eo Culture Site in Thoai Son District, An Giang Province, Vietnam, American Sciences Research Journal for Engineering, Technology, and Sciences (ASRJETS), Vol 36, No1 (2017), pp.271-293, ISSN (Print) 2313-4410, ISSN (Online) 2313-4402. http://asrjetsjournal.org/index.php/American_Scientific_Journal/article/viewFile/3393/1271

- Thắng, Đặng Văn, 2018: Hindu Temples in Champa culture in the middle of Vietnam, International Journal of Advanced Research (IJAR), ISSN 2320-5407, January 2018. http://www.journalijar.com/currentissue $/$ ?mn=01\&yr $=2018 \& \mathrm{Ln}=$ upload21926 